\title{
Antecedents of project managers turnover intention: Psychological distress as mediator
}

\author{
Shuja ul Islam ${ }^{1 *}$, Rida Chughtai ${ }^{2}$ \\ 1,2 FAST School of Management, National University of Computer and Emerging Sciences, Islamabad, Pakistan
}

\section{Keywords \\ Project complexity \\ Project risk \\ Stakeholder relationship \\ Psychological distress \\ Intention to leave \\ Intrinsic motivation}

Received: 1 October 2019

Accepted: 5 November 2019

Published: 23 December 2019

\begin{abstract}
This study aims to address the behavior of project managers and project team leaders working in software houses in Pakistan. that how project managers and project team leads react when they have to deal with complex and riskier projects. This study explores the effects of project-related factors (project risk and shareholder relationship) on the software houses project manager's intention to leave their jobs and psychological distress. The mediating effect of intrinsic motivation is also explored. This study intends to overcome the existing gap, as, in literature, these variables' relationship is not studied. It was a time lag study based on two online questionnaires for data collection. Data was collected from the project managers and project team leaders of the software houses. A total of 40 software houses were used for data collection. The findings suggest that psychological distress mediates project risk, stakeholder relationship, and intention to leave. There was no significant mediating effect of intrinsic motivation. The results showed that the project manager's intention to leave depends on psychological distress. The data was collected from the software houses of twin cities of Pakistan. So its results cannot be generalized to all software houses operating in Pakistan. Data were obtained from software houses operating at large levels involved in multiple projects; less data was collected from the software houses operating at a small level. This study contributes to the existing body of knowledge of project management. The findings of this study will help the owners of project-based IT organizations to understand the project-related factors' contribution in developing project managers and project team leads intention to leave the job and how these factors affect their mental health that can lead to negative effects.
\end{abstract}

(C) 2019 The Author(s). Published by TAF Publishing.

\section{INTRODUCTION}

The turnover expense of IT employees is huge as they possess specialized skills and knowledge that is difficult to replace (Joseph, Ng, Koh, \& Ang, 2007; Liu \& Dong, 2016; McKnight, Phillips, \& Hardgrave, 2009). Employee turnover intention has a huge impact on the organization, especially projectized organizations face more challenges as the success of their projects depend on the skills of employees. The study conducted by McKnight et al. (2009) suggest that in IT sector workplace factors (job security, Structural fairness and information sharing) have greater effect on IT personnel turnover intention as compared to job characteristics. The better workplace factors can help in retention of IT personals. Also, the IT personnel turnovers become more significant impact, when it comes to the turnover of project managers.

Most of the IT project failure occurs due to lack of understanding about how to deal with the project risk (Barki, Rivard, \& Talbot, 1993; Charette, 1996; McFarlan, 1982). IT projects are more exposed to risk and complexities, creating a lot of pressure on project managers that can effect their psychological health and eventually their career. According to recent studies the work related stress in project based organizations is increasing in managers. Project managers operating in project based firms face high levels of stress as compared to other occupations which is a serious concern (Cohen \& Bailey, 1997; Noblet, Rodwell, \& McWilliams, 2001; Onegi, Eser, \& Korkmaz, 2019). Due to the increase accountability and high project risk project managers often face high level of stress (Joseph et al., 2007). The psycholog-

\footnotetext{
* corresponding author: Shuja ul Islam

†email: shujaul.islam@nu.edu.pk
} 
ical distress not only affects the health of manager, in fact it affects the overall success of the project (Albrecht, 1979). In project management, stakeholders are considered as the most important part of the project and introduced as a separate knowledge area in Project Management Body of Knowledge (PMBOK). Stakeholders relationship management is the critical aspect in the project based organizations. Most of projects fail due to lack of communication between project managers, project team leads and internal stakeholders (Bourne \& Walker, 2005; Turner \& Zolin, 2012). The project success has positive relationship with the stakeholder relationship management. The good relationship of stakeholder with project managers and project teams ensure the timely completion of project. Project managers are responsible for the management of the stakeholders' relationship. They have to make sure that all the things related to project are communicated properly to the project stakeholders (Bourne \& Walker, 2008).

Retaining and motivating project managers in IT industry is a difficult task (Smits, McLean, \& Tanner, 1993). The past research work done on IT industry shows that IT managers' turnover intention is reduced when they experience high hygiene factors (Tan \& Igbaria, 1994). Intrinsic motivation is developed when employee feel that the work is interesting and enjoyable. Intrinsic motivation is established on the basis of human perception that how employee perceives his work (Deci, 1972). The workers that experience high level of intrinsic motivation will less likely be involve in turnover behaviour (Ambrose \& Kulik, 1999). The research on IT manager's intrinsic motivation and its impact on turnover intention remain unexplored.

A large number of antecedents have been identified that effect the intention to leave. However, in project management literature very less work has been done on project managers' intention to leave. Also the literature on risk management, the impact of project risk is studied on project success but pays no attention at the managerial level that how it lead to turnover intention. Similarly, few studies have deliberated the impact of psychological distress on managers' turnover intention in construction projects but no work is done in the IT Sector. This study fills the existing gap in literature by looking deep in to how project risk and stakeholder relationship effect turnover intentions of software houses project managers with the mediating effect of psychological distress and intrinsic motivation First objective of the research is to study the impact of project risk and Internal Stakeholder Relationship (ISR) on managers' turnover intention mediated through psychological distress. Secondly, to study the impact of project risk and ISR on managers' turnover intention mediated through intrinsic motivation.

\section{LITERATURE REVIEW}

\section{Turnover Intention}

Turnover intention refers to the subjective estimation of an individual regarding the probability of leaving an organization in the near future (Mowday, Porter, \& Steers, 1982; Reza, Rusidah, \& Forasidah, 2017). Intention to leave is defined as a "Conscious and deliberate willingness to leave the organization" (Tett \& John, 2006). Intention to leave work depends on two things one deals with employees own attitudes and other with the organizational and managerial behaviours (Cho, Johanson, \& Guchait, 2009). It can be categorized as voluntary or involuntary action based on internal and external factors of the work place. The factors like availability of better job opportunities, organizational factors, social factors and external factors has potential to promote desire of employee to leave job (Cotton \& Tuttle, 1986; Zarb, 2016). Literature shows that the terms intention to leave, intention to quit and turnover intention tap the similar concepts. In past researches, lot of work has been done on these variables in the field of Human Resource (HR) and marketing (Hatcher, 1999). In field of human resource development impact of job commitment, job satisfaction, Job stress, unemployment, government rules and regulations, personality traits, perceived organizational support and organizational commitment effect on the intention to leave has been studied (Hatcher, 1999; Harris, Harris, \& Harvey, 2008). Turnover intention is believed as harmful for the organizations success and employees intend to turnover due to poor human resource management (Slavich, Cappetta, \& Giangreco, 2014). Parker and Skitmore (2005) categorised the project manager's turnover intentions in to two groups, the group one was based on personal development and career motives and group two include project management role and dissatisfaction with organization culture. Increased job stress in employees effect the turnover intentions, some studies have used job stress as mediator in predicting core job factors impact on the turnover intentions of the employees (Chen, Lin, \& Lien, 2011). The turnover intentions leads to psychological detachment from the work that act as source of stress in employees professional and family life (Andres, Moelker, \& Soeters, 2012). The project managers and project leaders face high level of job stress as they have to meet the aggressive project timelines and project extensions (Smits et al., 1993). Study conducted by Nuhn, Heidenreich, and Wald (2016) shows that task related factors affect the turnover intention of employees that operate in project teams in temporary organiza- 
tions. Also decreased organizational commitment and job satisfaction plays the significant role in turnover (Eckhardt, Laumer, Maier, \& Weitzel, 2016). But there is no significant work done that can show the impact of project related factors (project risk and stakeholder relationship) on project manager's intention to leave.

\section{Project Risk}

Risk management is an important aspect of IT project management (Taylor, Artman, \& Woelfer, 2012). According to the Delphi studies conducted on project risk shows that the user risk and project management risk are critical for the success of the IT projects (Schmidt, Lyytinen, Keil, \& Cule, 2001). IT project managers are responsible for managing the project risks. Most of information system projects fail due to the countless project risks that threaten the project successes (Nelson, 2007; Schmidt et al., 2001; Wallace \& Keil, 2004). The risk factor can act as a hindrance in the effective completion of the successful IT project (Schmidt et al., 2001). Literature shows that project risk has negative impact on both firm and managerial level (Perminova, Gustafsson, \& Wikström, 2008).

According to Jones (1994) projects that are information technology based face additional risk factors as compared to non-information technology related projects. These risk factors include tough schedules for meeting deadlines, changing requirements of the users, increased project cost and poor quality of work due to work overload. In literature software project risk is classified in six dimensions; project complexity, project planning, user risk, requirement risk, organization environment and project team risk. These dimensions are made on the basis of forty risk factors (Wallace, Keil, \& Rai, 2004).

IT personnel have high tendency to leave their job (Leung, Chan, \& Olomolaiye, 2008), especially, the retention of IT managers is important as the firms highly rely on their professional skills of managing riskier and complex projects (Bourne \& Walker, 2006). Studies have shown that the perception of risk plays an important role, the project managers that perceive higher levels of risk shows less commitment to a failing project (Keil et al., 2000).

\section{Stakeholder Relationship}

According to PMBOK guide stakeholders are defined as "Individual, group, or organization who may affect or be affected by, or perceive itself to be affected by a decision, activity, or outcome of a project, who may be actively involved in the project or have interests that may be positively or negatively affected by the performance of completion of the project" (Haynes \& Love, 2004).

In the field of project management, the stakeholder management theory has gained huge attention (Bourne \& Walker, 2006). Managing stakeholder is a critical factor for the completion of a successful project as the stakeholders are the ones for whom the project is done (Jiang, Klein, $\mathrm{Wu}$, \& Liang, 2009; Bourne \& Walker, 2006). Project success depends on the effective management of stakeholder relationships the stakeholder can be internal people of the organization or the external people (McElroy \& Mills, 2000). Good relationship with project stakeholders help to get effective results but in case of poor relationship with project stakeholders will negatively effect project success (Bourne \& Walker, 2008). Project managers and project team leaders are responsible for identifying the right stakeholders and their level of influence in the project. The project managers and project team leaders have to make sure that the actual project outcomes meet the stakeholder's expectations. They are also responsible for ensuring effective communication to the stakeholders about the project (Jiang et al., 2009). According to Freeman, Martin, and Parmar (2007), the stakeholders are classified in two categories external (secondary stakeholder) and internal (primary stakeholder). The people that are indirectly involved in project are known as external stakeholders. The group of people that are directly involved in project are known as internal stakeholder. It is important for employees to maintain strong relationship with both stakeholders as they can influence the decisions (Mitchell, Agle, \& Wood, 1997). Literature shows that stakeholder can influence project success and project scope (Bourne \& Walker, 2005). The success of software industry projects depends on the effective communication between project managers, project team members and the stakeholders (Ghobadi \& Mathiassen, 2016). The literature shows that construction industry project success depend on the good relationship between project managers and project stakeholders. The stakeholders have the potential to influence the project manager's decisions (Bourne \& Walker, 2005).

\section{Psychological Distress}

The term Psychological distress is used to refer to mental health issues that affect the organizations environment."Psychological distress is a non-specific syndrome that is comprised of self-devaluation, irritability, aggressiveness, anxiety, depression, and social withdrawal" (Demerouti, Bakker, Nachreiner, \& Schaufeli, 2001). The study conduct by (Linda \& Sharlene, 1988) revealed that project support is not related to psychological distress, 
whereas, the project hindrance and social environment of employees have a positive relationship with psychological distress. Literature shows that employees with high project involvement show low level of psychological distress. Employees working in uncertain, turbulent and risker environment have chances to experience psychological distress (Chiocchio et al., 2010). Literature shows that psychological distress is developed on the basis of the designation and position of the employee in the organization. Unskilled employees face high psychological distress as compared to skilled ones (Chiocchio et al., 2010).

According to the job demand control theory job demands and job control effect the stress levels of workers (R. Karasek \& Tores, 1990). The Job Demand Control (JD-C) model suggests that the people having high control on the job demand are likely to experience no job strain so the managers that are able to manage their job demands effectively are likely to experience no psychological distress (R. A. Karasek, 1979).

The project based organizations face tight schedules, uncertainties and tough time lines that lead to stress in the project managers and project team leaders (Cohen \& Bailey, 1997). Most of the literature of project management has studied the impact of psychological distress on the performance of the project managers working in construction projects (Bowen, Govender, Edwards, \& Cattell, 2018; Haynes \& Love, 2004).The results of such studies showed that the stress decreased the construction project manager performance. Also it is suggested that the positive appraisal by stakeholder and proper stress counseling can help project manager in dealing with stress and can improve their performance (Leung et al., 2008).

H1: Psychological distress will mediate the influence of project risk on project managers' intention to leave.

H2: Psychological distress will mediate the influence of stakeholder relationship on project managers' intention to leave.

\section{Intrinsic Motivation}

Intrinsic motivation is defined as "Act of doing something because it is inherently interesting or enjoyable" (Deci, 1972). Intrinsic motivation is a mechanism that helps the management to reduce the employs turnover rate. Employees with high intrinsic motivation have low desire to leave the job as compared to the people having low intrinsic motivation. Most of studies suggest turnover intention and intrinsic motivation has negative relationship (Dysvik \& Kuvaas, 2011; Houkes, Janssen, de Jonge, \& Nijhuis, 2001; Lai \& Kapstad, 2009).
Past research shows that the intrinsic motivation has been used as both moderator and mediator in literature. The relationship of perceived organizational autonomy and work performance is moderated by the intrinsic motivation (Dysvik \& Kuvaas, 2011). Similarly the intrinsic motivation is used as mediator in human resource management literature. Most of the studies have shown that intrinsic motivation mediates the employee work performance, employee's creativity and psychological empowerment (Zhang \& Bartol, 2010).

In project based organizations literature the effect of intrinsic motivation on IT worker turnover has been studied. A study conducted by Thatcher, Liu, Stepina, Goodman, and Treadway (2006) shows that the intrinsic motivation affects the turnover intentions of the IT Workers. They also analysed the mediating effect of attitudes of IT personal on the relationship of intrinsic motivation and intention to turnover.

H3: Intrinsic motivation will mediate the influence of project risk on project manager intention to leave.

H4: Intrinsic motivation will mediate the influence of stakeholder relationship on project manager intention to leave.

\section{Theoretical Grounding JD-C theory}

According to the job demand control model of job stress, shows that employees who are in job environments that combine high demands, low control, and low support are at the highest risk for psychological disorder (?, ?). The psychological strain is caused due to the mismatch between the job demands and job resources. The past studies have shown that the job demands such as emotional demands, increased work pressure, complexity and lack of role clarity often lead to poor physical and mental health (Halbesleben \& Buckley, 2004). However Job resources such as supervisor support, positive feedback, performance appraisal, social support and independence for performing a task often lead to increased motivation which helps in developing strong organizational commitment, learning and work engagement (Taris \& Feij, 2004). Job resources help in building extrinsic motivation at work as they are required to deal with job demands and for achieving work goals. Also job resources motivate employee intrinsically by fulfilling the basic psychological needs of autonomy, competence and belongingness (Preacher \& Hayes, 2008). So the Psychological strain is caused by the grouping of high job demands and low job controls. The JD-C model suggest that the people having high control on the job demands will likely to expe- 
rience no job strain. So the managers that are able to manage their job demands effectively will likely to experience no psychological distress (R. A. Karasek, 1979). The risk of psychological stress can be lessened by altering factors in the workplace. Very little attention has been paid on how job conditions effect the intention to leave.

The JD-C model could be used to assess the relationship of job demand (Project risk and stakeholder relationship) and psychological distress to the outcome of intention to leave, and to determine whether psychological distress mediates the impact of project risk and stakeholder relationship on project manager's turnover intentions. In case of our study we classified project risk and stakeholder relationship as job demands because in project based organizations dealing with uncertainties and maintaining good relationship with employees both are the part of the job description of the project manager.

Similarly Job Demand Resource (JD-R) model can be used in case of intrinsic motivation. As this model suggests that job resources develop intrinsic motivation that will help to deal with job demands (project risk and stakeholder relationship) and increases organizational commitment (Schaufeli \& Bakker, 2004).

Also the JD-R model of burnout suggest that the effect of job demands on intention to leave are fully mediated by burnout (Demerouti et al., 2001). So this model can be used to address the mediating effect of psychological distress on the relationship of job demands (project risk and stakeholder relationship) on the turnover intention of the project managers.

\section{Stakeholder theory}

Stakeholders are defined as "any group or individual who can affect or is affected by the achievement of the organization's objectives" (Freeman, 2010). The stakeholder theory says that the firms should invest in their stakeholders as they play an important role in the success of the organization. It is important to establish good relationship with both internal and external stakeholders. In the field of project management, the stakeholder management theory has gain huge attention. Managing stakeholder is a critical factor for the completion of a successful project as the stakeholders are the ones for whom the project is done (Bourne \& Walker, 2006; Jiang et al., 2009). Project success depend on the effective management of stakeholder relationships the stakeholder can be internal people of the organization or the external people (McElroy \& Mills, 2000). The stakeholder theory support the concept of development of good relationship with the project stakeholders, so stakeholder theory can be used in case of both psychological distress and intrinsic motivation. As this theory suggests that stakeholders are the key for project success, so good relationship with stakeholder will develop the intrinsic motivation and reduce the psychological distress that will help to deal with turnover intentions.

\section{Theoretical Framework}

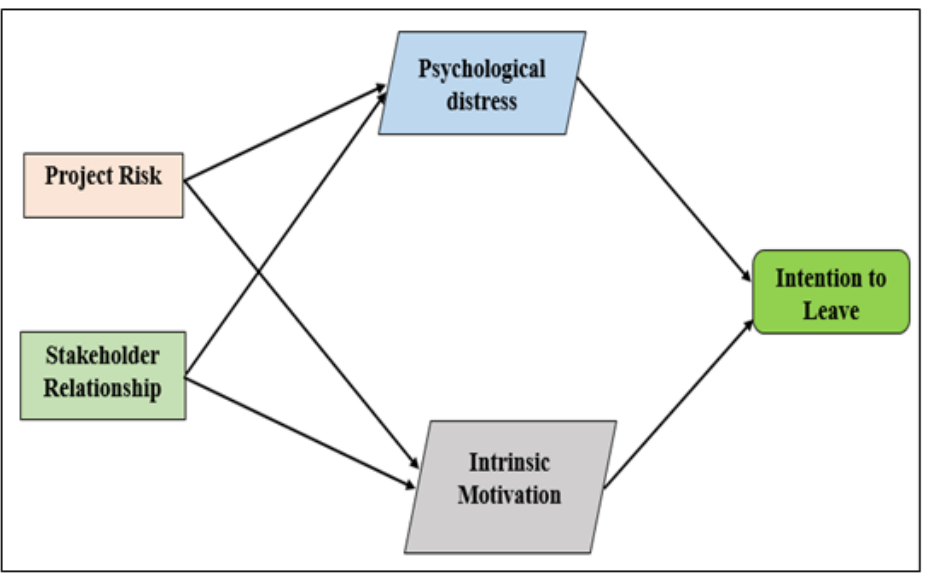

FIGURE 1. Mediation framework

\section{RESEARCH METHODOLOGY}

\section{Sample}

On the basis of convenience sampling data was collected from software houses operating in Islamabad and Rawalpindi. Sample frame was made based on 50 software houses. On the bases of convenience sampling data was col- lected from 40 software houses. The sample size was $N=$ 102. The minimum age was 22 and maximum was 41 years. Out of 102 respondents 80 were male and 22 were female project managers and project team leaders. 


\section{Data Collection}

It was a time lag study; two questionnaires were used for data collection. Questionnaires constitute of two parts demographics and variables. Questionnaires were filled by the project managers and project team leaders of the software houses. On the basis of completion of first questionnaire responses the second questionnaire was floated to respondents after one week. In order to ensure the timely completion of questionnaire, the data was collected through both methods; online survey method and by self-administered questionnaire method.

\section{Measures}

All the scales were adopted from literature; some questions were modified according to the research requirement. The Cronbach alpha value was greater than 0.7 , so all the scales were reliable for analysis. Scales used in this study were adopted from following research articles.

\section{Intention to leave}

For intention to leave 3-item scale was adapted from (Irving, Coleman, and Cooper 1997). Five-Point Likert scale was used for scoring items ( 1 = strongly disagree; 5 = strongly agree).

\section{Psychological distress}

The Kessler Psychological Distress Scale (Andrews \& Slade, 2001) was used for measuring psychological distress. The psychological distress scale involves 10 questions related to emotional states each with a 5 point response scale $(5=$ all of the time; 1 = none of the time).

\section{Intrinsic motivation}

For measuring the mediator intrinsic motivation scale based on 4 items was used (Low, Cravens, Grant, \& Moncrief, 2001). Five-point Likert scale was used for scoring the items ( 1 = strongly disagree; 5 = strongly agree).

\section{Project risk}

For measuring project risk the questionnaire based on six dimensions of risk was taken from the work ofWallace and Keil (2004). Slight changes were made in the wording of the questions. Five-Point Likert scale was used for scoring items ( 1 = strongly disagree; 5 = strongly agree).

\section{Stakeholder relationship}

Stakeholder relationship was measured by using ISR and External Stakeholder Relationship (ESR) scales (Mazur \&
Pisarski, 2015). Five-Point Likert scale was used for scoring items ( 1 = strongly disagree; 5 = strongly agree).

\section{DATA ANALYSIS}

For analysis, we used structural equation modelling to test hypotheses. We used the Smart Partial Least Saquare (PLS) 2.0 (beta) (Ringle, Sven, \& Alexander, 2010) software to analyse the data. The analysis was conducted in two step as by Anderson and Gerbing (1988), the measurement model was first tested followed by structural model in order to test the hypotheses.

\section{Measurement Model Estimation}

Firstly, the validity i.e., convergent and discriminant validity, and reliability of all constructs were checked. Table 1 shows all loadings were higher than 0.6 which is the threshold suggested by Hair, Ringle, and Sarstedt (2013). Also the Average Variance Extracted (AVE) of all constructs exceeded 0.5 (Bagozzi \& Yi, 1988) while the composite reliability scores (CR) were all higher than 0.7 (Hair et al., 2013). These values of loading and AVE confirms the convergent validity. For discriminant validity, the value of AVE for each construct should be higher than its correlation value and other construct of the model (Fornell \& Larcker, 1981; Fornell, 1994). As shown in Table 2, all constructs meet this criterion indicating the constructs have discriminant validity.

\section{STRUCTURAL MODEL ESTIMATION}

We tested our hypotheses using structural equation modelling. The $t$-statistic for path cofficients were obtained using a bootstrapping procedure with 500 resamples. Figure 1 shows the structural model with path co-efficients, significance levels, $R$-square values, and the factor loadings. As shown in Figure 1 and Table 3, there is no relationship ( $\beta=0.176$, n.s.) between Project risk and Intention to leave and also no direct relationship between Internal Stakeholder and Intention to leave( $\beta=-0.187$, n.s.). In order to test the mediation hypothesis H1, H2, H3 and H4 the Preacher and Hayes (2004), Preacher and Hayes (2008) method of bootstrapping the indirect effect is applied. For hypothesis $H 3$, the mediation analysis showed that the indirect effect $(\beta=0.122, p<0.05)$ is significant with a $t$-value of 1.69 with the upper limit and lower limit of Boot CI: [LL $=0.00$, UL $=0.244]$, as shown in Table 3 . Thus, full mediation of impact of project risk on turnover intention through psychological distress is confirmed, indicating that $\mathrm{H} 1$ was supported. 
TABLE 1. Creteria for Indicating constructs

\begin{tabular}{|c|c|c|c|c|c|}
\hline Construct & Intrinsic Motivation & AVE & Composite & Reliability & $R$ Square \\
\hline \multirow[t]{3}{*}{ Turnover Intention } & int_1 & 0.868529 & 0.597374 & 0.814808 & 0.311015 \\
\hline & int_2 & 0.665382 & & & \\
\hline & int_3 & 0.771392 & & & \\
\hline \multirow[t]{4}{*}{ Intrinsic Motivation } & IM_1 & 0.82552 & 0.728603 & 0.914772 & 0.398971 \\
\hline & IM_2 & 0.877672 & & & \\
\hline & IM_3 & 0.848859 & & & \\
\hline & IM_4 & 0.861428 & & & \\
\hline \multirow[t]{9}{*}{ ISR } & ISR_1 & 0.654189 & 0.519124 & 0.906192 & \\
\hline & ISR_10 & 0.750498 & & & \\
\hline & ISR_11 & 0.730337 & & & \\
\hline & ISR_12 & 0.746867 & & & \\
\hline & ISR_4 & 0.686817 & & & \\
\hline & ISR_6 & 0.663245 & & & \\
\hline & ISR_7 & 0.646638 & & & \\
\hline & ISR_8 & 0.804409 & & & \\
\hline & ISR_9 & 0.782868 & & & \\
\hline \multirow[t]{9}{*}{ Psychological Distress } & psy_10 & 0.779827 & 0.554355 & 0.924003 & 0.117586 \\
\hline & psy_2 & 0.789136 & & & \\
\hline & psy_3 & 0.761084 & & & \\
\hline & psy_4 & 0.794592 & & & \\
\hline & psy_5 & 0.797209 & & & \\
\hline & psy_6 & 0.799786 & & & \\
\hline & psy_7 & 0.836034 & & & \\
\hline & psy_8 & 0.54525 & & & \\
\hline & psy_9 & 0.769161 & & & \\
\hline \multirow[t]{20}{*}{ Project Risk } & oe_3 & 0.716955 & 0.510579 & 0.961099 & \\
\hline & oe_4 & 0.694123 & & & \\
\hline & pp_1 & 0.738253 & & & \\
\hline & pp_2 & 0.795777 & & & \\
\hline & pp_3 & 0.801542 & & & \\
\hline & pp_4 & 0.703485 & & & \\
\hline & pp_5 & 0.738135 & & & \\
\hline & pp_6 & 0.804002 & & & \\
\hline & pp_7 & 0.80149 & & & \\
\hline & ptr_1 & 0.722156 & & & \\
\hline & ptr_2 & 0.661905 & & & \\
\hline & ptr_3 & 0.741475 & & & \\
\hline & ptr_4 & 0.746045 & & & \\
\hline & ptr_5 & 0.688297 & & & \\
\hline & rr_2 & 0.722359 & & & \\
\hline & rr_3 & 0.769679 & & & \\
\hline & ur_2 & 0.723824 & & & \\
\hline & ur_3 & 0.750395 & & & \\
\hline & ur_4 & 0.682615 & & & \\
\hline & ur_5 & 0.74499 & & & \\
\hline
\end{tabular}

TABLE 2. Intrinsic Motivation

\begin{tabular}{llllll}
\hline \hline & Intrinsic Motivation & Project Risk & Psy Distress & Stakeholder Relationship & Turnover Intention \\
\hline Intrinsic Motivation & 0.853 & & & & \\
Project Risk & -0.379 & 0.714 & & & \\
Psy Distress & -0.281 & 0.271 & 0.744 & & \\
Stakeholder Relationship & 0.586 & -0.256 & -0.272 & 0.721 & 0.772 \\
Turnover Intention & -0.123 & 0.180 & 0.557 & -0.167 & \\
\hline \hline
\end{tabular}


TABLE 3. Hypothesis Testing

\begin{tabular}{llllll}
\hline \hline Hypothesis & Relationship & Beta Value & Std Error & $\boldsymbol{t}$-Value & Decision \\
\hline H1 & Project Risk $\rightarrow$ Psy. Distress $\rightarrow$ Turnover Intention & 0.122 & 0.062 & $1.96^{*}$ & Supported \\
H2 & Stakeholder Relationship $\rightarrow$ Psy. Distress $\rightarrow$ Turnover Intention & -0.123 & 0.056 & $-2.18^{*}$ & Supported \\
H3 & Project Risk $\rightarrow$ Intrinsic Motivation $\rightarrow$ Turnover Intention & 0.009 & 0.024 & -0.367 & Not Supported \\
H4 & Stakeholder Relationship $\rightarrow$ Intrinsic Motivation $\rightarrow$ Turnover Intention & 0.019 & 0.050 & 0.38 & Not Supported \\
\hline \hline
\end{tabular}

\section{DISCUSSION}

The results of the study suggested that project risk and stakeholder relationship have no statistically significant effect on project managers and project team leader's intention to leave. So project managers and project team leads are influenced by other factors but not by the project related factors (Perminova et al., 2008).

In case of psychological distress, the project risk showed positive significant relationship with psychological distress. The project risk was measured on the basis of six dimensions that include; project complexity, project planning risk, user risk, requirement risk, organization environment and project team risk (Wallace et al., 2004). The increased project risk increases the psychological distress. The project managers and project team leaders working on riskier software projects develop high level of psychological distress, whereas the software houses with less project risk their project managers and project team leaders experience low level of psychological distress. Similarly stakeholder relationship showed negative significant relationship with psychological distress. The software houses that establish good relationship with their stakeholders are likely to have low levels of psychological distress in project managers. The stakeholders are the important part of the project and satisfying their needs is the duty of project managers. So if project managers and project team leaders have bad relationships with the project stakeholder then they are likely be going to suffer from increased psychological distress, because the success of the project can only be achieved by effective management of the stakeholder relationship (Bourne \& Walker, 2006; Jiang et al., 2009).

The mediation analysis result showed full mediation effect of the psychological distress on the relationship of project factors and the intention to leave job. The full mediation suggests that project risk, and stakeholder's relationship management has no direct effect on the intention to leave. But in the presence of mediator the project related factor has an indirect effect on the intention to leave. The project risk showed positive significant relationship with psychological distress which in turn showed highly significant positive relationship with project manager's intention to leave. The higher the project risk and the higher will be the psychological distress that will mediate the relationship and increases the project manager's intention to leave the job (JD-R model of burnout). Whereas, the stakeholder relationship showed negative significant relationship with the psychological distress that in turns has highly significant positive mediating effect on intention to leave. The project managers having good relationship with stakeholders will likely to have low psychological distress that in turn will mediate the relationship and decrease the project managers and project team leads intention to leave.

The intrinsic motivation does not mediate the influence of project risk and stakeholder relationship on the intention to leave. It was supposed that project managers and project team leads with high level of intrinsic motivation will not leave the job despite of the high level of project risk. But the mediation analysis recommend that there is no effect of intrinsic motivation on the association of independent and dependent variables.

The overall results show that the Project managers and project team leads working in software houses of twin cities of Pakistan suffer from psychological distress which is developed on the basis of increased project risk. Also, a poor relationship with stakeholders increases the psychological distress. Due to the mediating effect of psychological distress project managers and project teams lead intention to leave increased.

\section{CONCLUSION}

The results of the study highlight that project managers and project team leaders working in software industry suffer from psychological distress. As the software development industry have to meet deadlines and their stakeholder expectations, there is no flexibility in things and chances of error are supposed to be zero so this rigid environment of the industry effect the mental health of the project managers and project team leads. Past studies suggest that psychological distress occur due to persons own internal factors that further effects the performance of the manager but the results of this study suggest that the external factors related to project contribute in developing psychological distress in project manager and project team leaders. The bad relationships with stakeholders increases the psychological distress, the software houses should provide a proper platform and mechanism to their project managers and project team 
leaders that will help them in developing good relationship with the project stakeholders. The software houses should use risk management process that will help them to identify the possible risk. It is human nature that when they have to deal will unexpected things they become psychologically disturbed, so the software industry should provide project managers and project team leaders with risk management training, this will help in decreasing the psychological distress. The software houses should create flexible environment where people can interact and socialize as this will also help in reducing the psychological distress. The management of psychological distress in software houses is important as it effects the project managers and project team leader's turnover intention. Eventually, the turnover expense of a skilled project manager has a huge impact on the overall project success and the firm's reputation.

\section{LIMITATION AND FUTURE DIRECTION}

The study contains some limitations. Firstly, this study confronts the sample size limitation; only 102 responses were used due to the fact that data was collected from the software houses operating in twin cities of Pakistan. Secondly, the results of this study cannot be generalized to every software house project manager and project team leader working in Pakistan as data was only collected from Rawalpindi and Islamabad software houses. Culture is also another important aspects, the nature of people and business processes vary from culture to culture. People react differently to the situations, so it varies from culture to culture. Lastly data was obtained from software houses that are operating at large level (involved in multiple projects), less data was collected from the small scale software houses. The future researcher can use psychological distress and intrinsic motivation as independent variable and intention to leave as dependent variable. This study focused on project managers and project team leaders tso future researcher can consider the employees working in software houses as their unit of analysis.

\section{IMPLICATIONS}

This study contributes to the existing body of knowledge of project management. The results positively contribute to the literature of stakeholder's relationship management in case of project based firms. The stakeholders are the key players that can affect the project success and failure. The results of this study shows that the psychological distress in IT sector can effectively be managed by developing good relationship with both internal and external stakeholders of the project. Stakeholders have huge influence on the project managers as they are sponsors of the project. So it is important for project managers to maintain strong relationship with their stakeholders. This study adds a new perspective to the IT industry, that support the concept that IT professional face psychological distress because of increased project risk, and due to poor relationship with stakeholder. The increased psychological distress positively contributes in developing project manager's turnover intention. So the results suggest that managing psychological distress is an important aspect in software industry.

The major implication of this paper for project managers of software houses is that they can achieve better productivity and project success by effectively managing the stakeholder relationship. The stakeholders have potential to effect the project managers and project team's career and mental health. This paper shows that the psychological distress in software houses can effect the career path of project managers and lead them towards the turnover of the job. The turnover of a competent project manager has adverse effect on the project success. Results of this study help the project managers and software houses owners to understand how project factors (project risk and Stakeholder relationship management) effect the project managers and team leads mental health.

\section{REFERENCES}

Albrecht, K. (1979). Stress and the manager. Engelwood Cliffs, NJ: Prentice-Hall Inc.

Ambrose, M. L., \& Kulik, C. T. (1999). Old friends, new faces: Motivation research in the 1990s. Journal of Management, 25(3), 231-292. doi:https://doi.org/10.1177/014920639902500302

Anderson, J. C., \& Gerbing, D. W. (1988). Structural equation modeling in practice: A review and recommended two-step approach. Psychological Bulletin, 103(3), 411-423. doi:https://doi.org/10.1037/0033-2909.103.3.411

Andres, M., Moelker, R., \& Soeters, J. (2012). The work-family interface and turnover intentions over the course of projectoriented assignments abroad. International Journal of Project Management, 30(7), 752-759. doi:https://doi.org/ 10.1016/j.ijproman.2012.01.006

Andrews, G., \& Slade, T. (2001). Interpreting scores on the kessler psychological distress scale (K10). Australian and New Zealand Journal of Public Health, 25(6), 494-497. doi:https://doi.org/10.1111/j.1467-842x.2001.tb00310.x 
Bagozzi, R. P., \& Yi, Y. (1988). On the evaluation of structural equation models. Journal of the Academy of Marketing Science, 16(1), 74-94. doi:https://doi.org/10.1007/bf02723327

Barki, H., Rivard, S., \& Talbot, J. (1993). Toward an assessment of software development risk. Journal of Management Information Systems, 10(2), 203-225. doi:https://doi.org/10.1080/07421222.1993.11518006

Bourne, L., \& Walker, D. H. (2006). Visualizing stakeholder influence: Two Australian examples. Project Management Journal, 37(1), 5-21. doi:https://doi.org/10.1177/875697280603700102

Bourne, L., \& Walker, D. H. (2008). Project relationship management and the stakeholder circle. International Journal of Managing Projects in Business, 1(1), 125-130. doi:https://doi.org/10.1108/17538370810846450

Bourne, L., \& Walker, D. H. T. (2005). Visualising and mapping stakeholder influence. Management Decision, 43(5), 649-660. doi:https://doi.org/10.1108/00251740510597680

Bowen, P., Govender, R., Edwards, P., \& Cattell, K. (2018). Work-related contact, work family conflict, psychological distress and sleep problems experienced by construction professionals: An integrated explanatory model. Construction Management and Economics, 36(3), 153-174. doi:https://doi.org/10.1080/01446193.2017.1341638

Charette, R. N. (1996). Large-scale project management is risk management. IEEE Software, 13(4), 110-117. doi:https:// doi.org/10.1109/52.526838

Chen, M.-F., Lin, C.-P., \& Lien, G.-Y. (2011). Modelling job stress as a mediating role in predicting turnover intention. The Service Industries Journal, 31(8), 1327-1345. doi:https://doi.org/10.1080/02642060903437543

Chiocchio, F., Beaulieu, G., Boudrias, J.-S., Rousseau, V., Aubé, C., \& Morin, E. M. (2010). The project involvement index, psychological distress, and psychological well-being: Comparing workers from projectized and non-projectized organizations. International Journal of Project Management, 28(3), 201-211. doi:https://doi.org/10.1016/j.ijproman .2009 .05 .007

Cho, S., Johanson, M. M., \& Guchait, P. (2009). Employees intent to leave: A comparison of determinants of intent to leave versus intent to stay. International Journal of Hospitality Management, 28(3), 374-381. doi:https://doi.org/10.1016/ j.ijhm.2008.10.007

Cohen, S. G., \& Bailey, D. E. (1997). What makes teams work: Group effectiveness research from the shop floor to the executive suite. Journal of Management, 23(3), 239-290. doi:https://doi.org/10.1177/014920639702300303

Cotton, J. L., \& Tuttle, J. M. (1986). Employee turnover: A meta-analysis and review with implications for research. Academy of Management Review, 11(1), 55-70. doi:https://doi.org/10.2307/258331

Deci, E. L. (1972). The effects of contingent and noncontingent rewards and controls on intrinsic motivation. Organizational Behavior and Human Performance, 8(2), 217-229. doi:https://doi.org/10.1016/0030-5073(72)90047-5

Demerouti, E., Bakker, A. B., Nachreiner, F., \& Schaufeli, W. B. (2001). The job demands-resources model of burnout. Journal of Applied Psychology, 86(3), 499-512. doi:https://doi.org/10.1037/0021-9010.86.3.499

Dysvik, A., \& Kuvaas, B. (2011). Intrinsic motivation as a moderator on the relationship between perceived job autonomy and work performance. European Journal of Work and Organizational Psychology, 20(3), 367-387. doi:https://doi.org/ $10.1080 / 13594321003590630$

Eckhardt, A., Laumer, S., Maier, C., \& Weitzel, T. (2016). The effect of personality on IT personnel's job-related attitudes: Establishing a dispositional model of turnover intention across IT job types. Journal of Information Technology, 31(1), 48-66. doi:https://doi.org/10.1057/jit.2014.27

Fornell, C. (1994). Partial least squares. New York, NY: Blackwell.

Fornell, C., \& Larcker, D. F. (1981). Evaluating structural equation models with unobservable variables and measurement error. Journal of Marketing Research, 18(1), 39-50. doi:https://doi.org/10.1177/002224378101800313

Freeman, R. E. (2010). Strategic management: A stakeholder approach. Boston, MA: Cambridge University Press.

Freeman, R. E., Martin, K., \& Parmar, B. (2007). Stakeholder capitalism. Journal of Business Ethics, 74(4), 303-314. doi: https://doi.org/10.1007/s10551-007-9517-y

Ghobadi, S., \& Mathiassen, L. (2016). Perceived barriers to effective knowledge sharing in agile software teams. Information Systems Journal, 26(2), 95-125. doi:https://doi.org/10.1111/isj.12053

Hair, J. F., Ringle, C. M., \& Sarstedt, M. (2013). Partial least squares structural equation modeling: Rigorous applications, better results and higher acceptance. Long Range Planning, 46(1-2), 1-12. doi:https://doi.org/10.1016/j.lrp.2013.01 .001 
Halbesleben, J. R., \& Buckley, M. R. (2004). Burnout in organizational life. Journal of Management, 30(6), 859-879. doi: https://doi.org/10.1016/j.jm.2004.06.004

Harris, R. B., Harris, K. J., \& Harvey, P. (2008). An examination of the impact of supervisor on the relationship between job strains and turnover intention for computer workers. Journal of Applied Social Psychology, 38(8), 2108-2131. doi:https://doi.org/10.1111/j.1559-1816.2008.00383.x

Hatcher, T. (1999). How multiple interventions influenced employee turnover: A case study. Human Resource Development Quarterly, 10(4), 365-382. doi:https://doi.org/10.1002/hrdq.3920100407

Haynes, N. S., \& Love, P. E. (2004). Psychological adjustment and coping among construction project managers. Construction Management and Economics, 22(2), 129-140. doi:https://doi.org/10.1080/0144619042000201330

Houkes, I., Janssen, P. P., de Jonge, J., \& Nijhuis, F. J. (2001). Specific relationships between work characteristics and intrinsic work motivation, burnout and turnover intention: A multi-sample analysis. European Journal of Work and Organizational Psychology, 10(1), 1-23. doi:https://doi.org/10.1080/13594320042000007

Jiang, J. J., Klein, G., Wu, S. P., \& Liang, T. (2009). The relation of requirements uncertainty and stakeholder perception gaps to project management performance. Journal of Systems and Software, 82(5), 801-808. doi:https://doi.org/10.1016/ j.jss.2008.11.833

Jones, C. (1994). Assessment and control of software risks. London, UK: Yourdon Press.

Joseph, Ng, Koh, \& Ang. (2007). Turnover of information technology professionals: A narrative review, meta-analytic structural equation modeling, and model development. MIS Quarterly, 31(3), 547-560. doi:https://doi.org/10.2307/ 25148807

Karasek, R., \& Tores, T. (1990). Healthy work: Stress, productivity and the the reconstruction of working life. New York, NY: Sage Publications.

Karasek, R. A. (1979). Job demands, job decision latitude, and mental strain: Implications for job redesign. Administrative Science Quarterly, 24(2), 285-300. doi:https://doi.org/10.2307/2392498

Keil, M., Tan, B. C. Y., Wei, K.-K., Saarinen, T., Tuunainen, V., \& Wassenaar, A. (2000). A cross-cultural study on escalation of commitment behavior in software projects. MIS Quarterly, 24(2), 299-315. doi:https://doi.org/10.2307/3250940

Lai, L., \& Kapstad, J. C. (2009). Perceived competence mobilization: An explorative study of predictors and impact on turnover intentions. The International Journal of Human Resource Management, 20(9), 1985-1998. doi:https://doi .org/10.1080/09585190903142423

Leung, M. L., Chan, Y.-S., \& Olomolaiye, P. (2008). Impact of stress on the performance of construction project managers. Journal of Construction Engineering and Management, 134(8), 644-652. doi:https://doi.org/10.1061/(asce)0733 -9364(2008)134:8(644)

Linda, S. R., \& Sharlene, A. W. (1988). Personal goals and interpersonal support and hindrance as factors in psychological distress and well-being. Journal of Personality and Social Psychology, 55(2), 293-301. doi:https://doi.org/10.1037/ 0022-3514.55.2.293

Liu, H., \& Dong, X. (2016). Influence of social relations on knowledge conflicts-an empirical study from Chinese universities. Journal of Administrative and Business Studies, 2(1), 8-18. doi:https://doi.org/10.20474/jabs-2.1.2

Low, G. S., Cravens, D. W., Grant, K., \& Moncrief, W. C. (2001). Antecedents and consequences of salesperson burnout. European Journal of Marketing, 35(5/6), 587-611. doi:https://doi.org/10.1108/03090560110388123

Mazur, A. K., \& Pisarski, A. (2015). Major project managers' internal and external stakeholder relationships: The development and validation of measurement scales. International Journal of Project Management, 33(8), 1680-1691. doi:https://doi.org/10.1016/j.ijproman.2015.07.008

McElroy, B., \& Mills, C. (2000). Managing stakeholders. In, Gower handbook of project management. London, UK: Gower Publishing Limited.

McFarlan, W. (1982). Portfolio approach to information-systems. Journal of Systems Management, 33(1), 12-19.

McKnight, D. H., Phillips, B., \& Hardgrave, B. C. (2009). Which reduces IT turnover intention the most: Workplace characteristics or job characteristics? Information \& Management, 46(3), 167-174. doi:https://doi.org/10.1016/ j.im.2009.01.002

Mitchell, R. K., Agle, B. R., \& Wood, D. J. (1997). Toward a theory of stakeholder identification and salience: Defining the principle of who and what really counts. Academy of Management Review, 22(4), 853-886. doi:https://doi.org/10 
$.5465 / a m r .1997 .9711022105$

Mowday, R. T., Porter, L. W., \& Steers, R. (1982). Organizational linkages: The psychology of commitment, absenteeism, and turnover. San Diego, CA: Academic Press.

Nelson, R. R. (2007). IT project management: Infamous failures, classic mistakes, and best practices. MIS Quarterly Executive, 6(2), 120-130.

Noblet, A., Rodwell, J., \& McWilliams, J. (2001). The job strain model is enough for managers. Journal of Managerial Psychology, 16(8), 635-649. doi:https://doi.org/10.1108/eum0000000006304

Nuhn, H. F. R., Heidenreich, S., \& Wald, A. (2016). The role of task-related antecedents for the development of turnover intentions in temporary project teams. The International Journal of Human Resource Management, 29(15), 2284-2302. doi:https://doi.org/10.1080/09585192.2016.1239219

Onegi, M., Eser, Z., \& Korkmaz, S. (2019). Consumers' evaluation of glocal marketing strategies of global firms in Turkey: An example of a glocal product. International Journal of Business and Administrative Studies, 5(3), 109-118. doi:https:// dx.doi.org/10.20469/ijbas.5.10001-3

Parker, S. K., \& Skitmore, M. (2005). Project management turnover: Causes and effects on project performance. International Journal of Project Management, 23(3), 205-214. doi:https://doi.org/10.1016/j.ijproman.2004.10.004

Perminova, O., Gustafsson, M., \& Wikström, K. (2008). Defining uncertainty in projects a new perspective. International Journal of Project Management, 26(1), 73-79. doi:https://doi.org/10.1016/j.ijproman.2007.08.005

Preacher, K. J., \& Hayes, A. F. (2004). SPSS and SAS procedures for estimating indirect effects in simple mediation models. Behavior Research Methods, Instruments, \& Computers, 36(4), 717-731. doi:https://doi.org/10.3758/bf03206553

Preacher, K. J., \& Hayes, A. F. (2008). Asymptotic and resampling strategies for assessing and comparing indirect effects in multiple mediator models. Behavior Research Methods, 40(3), 879-891. doi:https://doi.org/10.3758/brm.40.3.879

Reza, F., Rusidah, S., \& Forasidah. (2017). The influence of interpersonal communication and organizational culture on job satisfaction of academics university Achmad Yani Banjarmasin. International Journal of Business and Economic Affairs, 2(6), 310-316. doi:https://doi.org/10.24088/ijbea-2017-25005

Ringle, C. M., Sven, W., \& Alexander, W. (2010). Finite mixture partial least squares analysis: Methodology and numerical examples. In, Handbook of partial least squares. Berlin, Germany: Springer.

Schaufeli, W. B., \& Bakker, A. B. (2004). Job demands, job resources, and their relationship with burnout and engagement: a multi-sample study. Journal of Organizational Behavior, 25(3), 293-315. doi:https://doi.org/10.1002/job.248

Schmidt, R., Lyytinen, K., Keil, M., \& Cule, P. (2001). Identifying software project risks: An international delphi study. Journal of Management Information Systems, 17(4), 5-36. doi:https://doi.org/10.1080/07421222.2001.11045662

Slavich, B., Cappetta, R., \& Giangreco, A. (2014). Exploring the link between human resource practices and turnover in multi-brand companies: The role of brand units' images. European Management Journal, 32(2), 177-189. doi:https:// doi.org/10.1016/j.emj.2013.06.001

Smits, S. J., McLean, E. R., \& Tanner, J. R. (1993). Managing high-achieving information systems professionals. Journal of Management Information Systems, 9(4), 103-120. doi:https://doi.org/10.1080/07421222.1993.11517981

Tan, M., \& Igbaria, M. (1994). Turnover and remuneration of information technology professionals in singapore. Information \& Management, 26(4), 219-229. doi:https://doi.org/10.1016/0378-7206(94)90094-9

Taris, T. W., \& Feij, J. A. (2004). Learning and strain among newcomers: A three-wave study on the effects of job demands and job control. The Journal of Psychology, 138(6), 543-563. doi:https://doi.org/10.3200/jrlp.138.6.543-563

Taylor, H., Artman, E., \& Woelfer, J. P. (2012). Information technology project risk management: Bridging the gap between research and practice. Journal of Information Technology, 27(1), 17-34. doi:https://doi.org/10.1057/jit.2011.29

Tett, R. P., \& John, P. M. (2006). Job satisfaction, organizational commitment, turnover intention, and turnover: Path analyses based on meta-analytic findings. Personnel Psychology, 46(2), 259-293. doi:https://doi.org/10.1111/j.1744-6570 .1993.tb00874.x

Thatcher, J. B., Liu, Y., Stepina, L. P., Goodman, J. M., \& Treadway, D. C. (2006). IT worker turnover: An empirical examination of intrinsic motivation. ACM SIGMIS Database, 37(2-3), 133-140. doi:https://doi.org/10.1145/1161345.1161361

Turner, R., \& Zolin, R. (2012). Forecasting success on large projects: Developing reliable scales to predict multiple perspectives by multiple stakeholders over multiple time frames. Project Management Journal, 43(5), 87-99. doi:https:// doi.org/10.1002/pmj.21289 
Wallace, L., \& Keil, M. (2004). Software project risks and their effect on outcomes. Communications of the ACM, 47(4), 68-73. doi:https://doi.org/10.1145/975817.975819

Wallace, L., Keil, M., \& Rai, A. (2004). Understanding software project risk: A cluster analysis. Information \& Management, 42(1), 115-125. doi:https://doi.org/10.1016/j.im.2003.12.007

Zarb, N. (2016). Stories from the middle: Perceptions of the roles of curriculum development managers in a Maltese further education organization. Journal of Advanced Research in Social Sciences and Humanities, 1(1), 18-29. doi:https:// doi.org/10.26500/jarssh-01-2016-0103

Zhang, X., \& Bartol, K. M. (2010). Linking empowering leadership and employee creativity: The influence of psychological empowerment, intrinsic motivation, and creative process engagement. Academy of Management Journal, 53(1), 107-128. doi:https://doi.org/10.5465/amj.2010.48037118 